\title{
Green leafy vegetables in diets with a 25:1 omega-6/omega-3 fatty acid ratio modify the erythrocyte fatty acid profile of spontaneously hypertensive rats
}

Melissa Johnson ${ }^{1 *}$, Ralphenia D. Pace ${ }^{1}$ and Wendell H. McElhenney ${ }^{2}$

\begin{abstract}
Background: In addition to the actual composition of the diet (i.e. nutrient composition, food groups), the omega6/omega-3 fatty acid ratio has been demonstrated to influence the tissue fatty acid profile and subsequently the risk for cardiovascular and other diseases. Likewise, the consumption of green leafy vegetables (GLVs) may favorably reduce the risks associated with disease. Although an $\sim 3: 1$ omega-6/omega-3 fatty acid ratio ( $\omega-6 / \omega-3 \mathrm{FAR})$ is recommended, the typical American diet has an 25:1 $\omega-6 / \omega-3$ FAR. Previous research affirms the ability of collard greens (CG), purslane (PL), and sweet potato greens (SPG) to improve the hepatic profile of spontaneously hypertensive rats (SHRs). The aim of the present study was to determine the influence of GLVs, incorporated (4\%) into diets with a 25:1 $\omega-6 / \omega-3$ FAR, on the erythrocyte fatty acid profile of male SHRs.
\end{abstract}

Methods: SHRs $(N=50)$ were randomly assigned to one of five dietary groups - standardized control (AIN-76A), Control (25:1 $\omega-6 / \omega-3$ FAR), CG (25:1 $\omega-6 / \omega-3$ FAR + 4\% CG), PL (25:1 $\omega-6 / \omega-3$ FAR + 4\% PL) or SPG (25:1 $\omega-6 / \omega-3$ FAR + 4\% SPG). Following 6 weeks consumption of diets, SHRs erythrocyte fatty acid profiles were determined by gas-liquid chromatography.

Results: Significantly lower percentages of total saturated fatty acids $(p<0.05)$ and greater percentages of polyunsaturated fatty acids were present among SHR erythrocytes following the consumption of diets containing CG, PL and SPG. Total polyunsaturated fatty acids were greatest among SHRs consuming diets containing purslane.

Conclusions: The present study demonstrates the ability of GLVs to mitigate the potential effects of an elevated $\omega-6 /$ $\omega-3$ FAR, which may contribute to an atherogenic fatty acid profile, inflammation and disease pathogenesis. Dietary recommendations for disease prevention should consider the inclusion of these GLVs, particularly among those consuming diets with an $\omega-6 / \omega-3$ FAR that may promote disease.

Keywords: Erythrocyte, Collard greens, Fatty acid profile, Omega-6/omega-3 fatty acid ratio, Purslane, Spontaneously hypertensive rat, Sweet potato greens

\footnotetext{
*Correspondence: mjohnson3@tuskegee.edu

${ }^{1}$ Department of Food and Nutritional Sciences, Tuskegee University,

Tuskegee, AL 36088, USA

Full list of author information is available at the end of the article
} International License (http://creativecommons.org/licenses/by/4.0/), which permits unrestricted use, distribution, and reproduction in any medium, provided you give appropriate credit to the original author(s) and the source, provide a link to the Creative Commons license, and indicate if changes were made. The Creative Commons Public Domain Dedication waiver (http://creativecommons.org/publicdomain/zero/1.0/) applies to the data made available in this article, unless otherwise stated. 


\section{Background}

Epidemiological and clinical evidence affirms that the consumption of diets with elevated omega-6/omega-3 fatty acid ratios $(\omega-6 / \omega-3$ FARs $)$ to be associated with an increased risk for hypertension, cardiovascular disease (CVD), diabetes and other chronic diseases [1-3]. Further, the dietary $\omega-6 / \omega-3$ FAR has been demonstrated to influence tissue fatty acid compositions [4, 5]. Although an $\sim 3: 1 \omega-6 / \omega-3$ FAR is recommended, the typical American (i.e. Western) diet has an $\sim 25: 1 \omega-6 / \omega-3$ FAR $[6,7]$. The excessive consumption of vegetable oils, processed foods and refined products, such as those observed in Western cultures, are believed to contribute to elevations in the dietary $\omega-6 / \omega-3$ FAR $[8,9]$. Conversely, plant-based diets, particularly those containing vegetables abundant in $\alpha$-linolenic acid, have lower $\omega-6 / \omega-3$ FARs [10] and are plentiful in antioxidant and bioactive compounds that have been associated with decrease risk for chronic disease [11-13].

Green, leafy vegetables (GLVs), rich of sources of antioxidants and bioactive compounds, have been demonstrated to improve antioxidant status and reduce the risks associated with disease [14]. Further, dietary patterns that promote the increased consumption of GLVs, such as the Mediterranean diet, may be beneficial in reducing the risks associated with disease pathogenesis [15-18]. In addition, the Dietary Approaches to Stop Hypertension (DASH) diet endorses the consumption of plants commonly found in the African American diet such as collard greens and sweet potatoes, for the reduction of the risks associated with hypertension and other chronic diseases [19-22].

Collard greens (Brassica oleracea), a traditional GLV with the diet of Americans living in the southern United States, in addition to purslane (Portulaca oleracea) and sweet potato greens (Ipomoea batatas L.), novel GLVs within the diet, are potent dietary reservoirs of antioxidant and bioactive compounds that may decrease disease risk $[23,24]$. Previous research has demonstrated the ability of collard greens, purslane and sweet potato greens to favorable modify the hepatic fatty acid profile of spontaneously hypertensive rats after 4 weeks consumption [25]. The aim of the present research study was to evaluate the influence of collard greens (CG), purslane (PL) and sweet potato greens (SPG), supplemented into diets with a $25: 1 \omega-6 / \omega-3$ FAR, on the erythrocyte fatty acid profiles of male spontaneously hypertensive rats.

\section{Methods}

\section{Animals and diets}

Fifty $(N=50)$ male spontaneously hypertensive rats (SHRs) , 4 weeks of age, were housed individually in clear polypropylene cages $(43 \times 27 \times 15 \mathrm{~cm})$, with temperature and relative humidity controlled at $70-72{ }^{\circ} \mathrm{C}$ and $50-55 \%$, respectively. SHRs were maintained on a 12:12 h light-dark photoperiod cycle. Following a 10 day acclimation period, SHRs were randomly assigned to one of four experimental dietary groups with a 25:1 $\omega-6 / \omega-3$ FAR: 1) Control, 2) $4 \%$ CG, 3) $4 \%$ PL, 4) 4\% SPG; 10 SHRs were assigned to the standardized control dietary group and received the AIN-76A diet for the duration of the research study. SHRs consumed the diets for 6 weeks. The compositions of the experimental diets are presented in Table 1. Animals were paid fed based on the average previous day's intake of SHRs consuming the experimental diets containing CG, PL and SPG. SHRs were allowed to consume water ad libitum.

Following a $24 \mathrm{~h}$ fast animals were anesthetized using a Ketamine-Acepromazine combination cocktail and then euthanatized via over-inhalation of carbon dioxide. Blood was collected via cardiac puncture, collected in heparin-coated tubes and centrifuged at $2500 \mathrm{rpm}$ at $10{ }^{\circ} \mathrm{C}$ for $30 \mathrm{~min}$ to separate plasma and erythrocytes. Following centrifugation, samples were stored at $-80{ }^{\circ} \mathrm{C}$ prior to analyses. Eight $(n=8)$ SHRs were randomly selected from each dietary group for the erythrocyte fatty acid profile analysis. The procedures involved in the care and use of the animals were approved by the Tuskegee University Animal Care and Use Committee.

Table 1 Ingredient composition of standardized control and experimental diets fed to SHRs for 6 weeks $^{a}$

\begin{tabular}{|c|c|c|c|c|c|}
\hline \multirow[b]{2}{*}{ Ingredient (\%) } & \multicolumn{5}{|c|}{ Dietary Group } \\
\hline & AIN-76A & C & $C G$ & $\mathrm{PL}$ & SPG \\
\hline Sucrose & 50.00 & 41.96 & 39.27 & 39.49 & 39.39 \\
\hline Casein (Vitamin Free) & 20.00 & 18.00 & 16.82 & 16.53 & 16.68 \\
\hline Corn Starch & 15.00 & 15.00 & 15.00 & 15.00 & 15.00 \\
\hline Powdered Cellulose & 5.00 & 5.00 & 5.00 & 5.00 & 5.00 \\
\hline AIN-76 Mineral Mix & 3.50 & 3.50 & 3.50 & 3.50 & 3.50 \\
\hline AIN-76 Vitamin Mix & 1.00 & 1.00 & 1.00 & 1.00 & 1.00 \\
\hline DL-Methionine & 0.30 & 0.30 & 0.30 & 0.30 & 0.30 \\
\hline Choline Bitartrate & 0.20 & 0.20 & 0.20 & 0.20 & 0.20 \\
\hline Ethoxyquin ${ }^{b}$ & 0.00 & 0.00 & 0.00 & 0.00 & 0.00 \\
\hline Corn Oil & 5.00 & 12.06 & 11.96 & 12.01 & 11.97 \\
\hline Soybean oil & - & 2.91 & 2.88 & 2.89 & 2.89 \\
\hline Fish Oil & - & - & - & - & - \\
\hline Cholesterol & - & 0.07 & 0.07 & 0.07 & 0.07 \\
\hline Collard Greens & - & - & 4.00 & - & - \\
\hline Purslane & - & - & - & 4.00 & - \\
\hline Sweet potato Greens & - & - & - & - & 4.00 \\
\hline
\end{tabular}

${ }^{a}$ Diets formulated and manufactured by the Division of Land O'Lakes Purina Feed, LLC, Richmond, IN. C, control; CG collard greens, PL purslane; SPG sweet

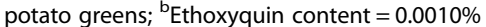

AIN-76A = AIN -76, standard rodent chow; $C$ (control diet) $=$ AIN-76A diet with a 25:1 $\omega-6 / \omega-3$ FAR; CG = AIN-76A diet with a 25:1 $\omega-6 / \omega-3$ FAR $+4 \%$ collard green powder; $\mathrm{PL}=\mathrm{AIN}-76 \mathrm{~A}$ diet with a $25: 1 \omega-6 / \omega-3 \mathrm{FAR}+4 \%$ purslane powder; SPG $=$ AIN-76A diet with a 25:1 $\omega-6 / \omega-3$ FAR $+4 \%$ sweet potato green powder 


\section{Erythrocyte fatty acid extraction}

Erythrocyte fatty acid methyl esters (FAMEs) were prepared following transesterification with boron trifluoride $\left(\mathrm{BF}_{3}\right.$, cat\# 3-3021, 12\% methanol, Supelco, Inc., Bellefonte, PA) using the procedures previously described by Masood et al. [26]. To approximately $0.01 \mathrm{~g}$ of SHR erythrocytes, $100 \mu \mathrm{l}$ of nonadecanoic acid (C19:0, Nu-Chek Prep, Inc., Elysian, $\mathrm{MN})$, dissolved in hexane $(1.0 \mathrm{ml})$, and $\mathrm{BF}_{3}$ $(1.0 \mathrm{ml})$ was added. Fatty acid methyl esters (FAMEs) were prepared by heating the mixture in a hot water bath at $55{ }^{\circ} \mathrm{C}$ for $90 \mathrm{~min}$ and subsequently placed in an ice bath for $5 \mathrm{~min}$. Hexane $(2.0 \mathrm{ml})$ and deionized water $(1.0 \mathrm{ml})$ were added, Pyrex glass culture tubes were flushed with nitrogen and vortexed for $15 \mathrm{~s}$. Following centrifugation at $2000 \mathrm{rpm}$ for $5 \mathrm{~min}$, the top organic layer, containing the FAMEs were collected and placed in gas chromatography (GC) vials for GC analysis. Samples were analyzed in duplicate.

\section{GC analysis of FAMEs}

Erythrocyte FAMEs were isolated and quantified using a HP $6890 \mathrm{~N}$ network gas chromatograph system (Agilent Technologies, Santa Clara, CA) equipped with a HP 7683 series automated injector, flame ionization detector and a DB23 fused silica capillary high resolution gas chromatograph column ( $60 \mathrm{~m}, 0.25 \mathrm{~mm}$, i.d., $0.25 \mu \mathrm{m}$ film thickness, J\&W Scientific, Folsom, CA). Data are expressed as percentages of total fatty acid.

\section{Statistical analysis}

Statistical analyses were conducted using analysis of variance software (SAS Software, Cary, NC). Duncan's post hoc procedures were performed to test if differences existed among SHRs consuming the different diets. Statistical significance was determined at $p<0.05$.

\section{Results}

Erythrocyte saturated fatty acid (SFA) concentrations (\% total fatty acids) of SHRs consuming diets with a 25:1 $\omega-6 / \omega-3$ FAR are presented in Table 2. Erythrocyte SFA concentrations were less among SHRs consuming diets containing CG $(41.72 \pm 2.71)$, PL $(39.65 \pm 1.41)$ and SPG $(38.63 \pm 0.80)$ in comparison to the standardized control $(71.82 \pm 3.43)$ and control $(45.25 \pm 2.36)$ diets. Palmitic acid was the most abundant erythrocyte SFA among SHRs, with SHRs consuming diets containing CG (24.71 \pm 1.60), PL (23.77 \pm 0.90$)$ and SPG $(23.05 \pm 0.46)$ - demonstrating lower percentages of this fatty acid in comparison to the standardized control $(60.05 \pm 5.47 ; p<0.05)$ and control $(27.08 \pm 1.61)$ diets.

Total monounsaturated fatty acids (MUFAs) among SHRs consuming diets containing GLVs ranged from $13.11 \pm 0.35$ (CG) to $14.98 \pm 0.70$ (SPG) and were slightly less than consuming the control diet $(15.10 \pm 0.25)$ (Table 3). Oleic acid, the most abundant MUFA present, was greatest among SHRs assigned to the control (9.41 \pm $0.33)$, CG $(8.56 \pm 0.35)$ and PL $(8.55 \pm 0.25)$ dietary groups. Significantly greater amounts of nervonic acid were present following the consumption of diets containing the GLVs in comparison to the standardized control diet; a slightly greater percentage of nervonic acid was present in the erythrocytes of SHRs consuming the control diet.

A significantly greater percentage of polyunsaturated fatty acids (PUFAs) were present in the erythrocytes of

Table 2 SHR erythrocyte saturated fatty acid composition (\%total fatty acids) following the consumption of diets with a 25:1 $\omega-6 / \omega-3$ FAR for 6 weeks ${ }^{\S}$

\begin{tabular}{|c|c|c|c|c|c|c|}
\hline \multirow[b]{2}{*}{ Fatty acid } & \multirow[b]{2}{*}{ Structure } & \multicolumn{5}{|l|}{ Dietary Group } \\
\hline & & AIN-76A & C & $C G$ & $\mathrm{PL}$ & SPG \\
\hline Capric & C10:0 & nd & nd & nd & nd & nd \\
\hline Undecanoic & C11:0 & nd & nd & nd & nd & nd \\
\hline Lauric & $\mathrm{C} 12: 0$ & $0.24 \pm 0.00^{\mathrm{a}}$ & $0.43 \pm 0.22^{\mathrm{ab}}$ & $0.06 \pm 0.01^{\mathrm{a}}$ & $0.12 \pm 0.04^{\mathrm{ab}}$ & $0.16 \pm 0.06^{b}$ \\
\hline Tridecyclic & C13:0 & nd & nd & nd & nd & nd \\
\hline Myristic & C14:0 & $0.17 \pm 0.02^{\mathrm{a}}$ & $0.23 \pm 0.05^{\mathrm{ab}}$ & $0.15 \pm 0.03^{a}$ & $0.20 \pm 0.03^{\mathrm{ab}}$ & $0.29 \pm 0.04^{b}$ \\
\hline Pentadecanoic & C15:0 & $0.12 \pm 0.01^{\mathrm{a}}$ & $0.14 \pm 0.01^{\mathrm{ab}}$ & $0.13 \pm 0.01^{\mathrm{ab}}$ & $0.17 \pm 0.02^{\mathrm{ab}}$ & $0.18 \pm 0.01^{b}$ \\
\hline Palmitic & C16:0 & $60.08 \pm 5.47^{\mathrm{a}}$ & $27.08 \pm 1.61^{b}$ & $24.71 \pm 1.60^{b}$ & $23.77 \pm 0.90^{b}$ & $23.05 \pm 0.46^{b}$ \\
\hline Heptadecanoic & C17:0 & nd & nd & nd & nd & nd \\
\hline Stearic & C18:0 & $11.15 \pm 2.80^{\mathrm{a}}$ & $16.80 \pm 1.04^{b}$ & $16.33 \pm 1.05^{b}$ & $15.01 \pm 0.52^{\mathrm{ab}}$ & $14.52 \pm 0.29^{\mathrm{ab}}$ \\
\hline Arachidic & C20:0 & nd & $0.20 \pm 0.01$ & nd & nd & nd \\
\hline Behenic & C22:0 & nd & nd & nd & nd & nd \\
\hline Lignoceric & C24:0 & nd & nd & nd & nd & nd \\
\hline Total SFAs & & $71.82 \pm 3.43^{a}$ & $45.25 \pm 2.36^{b}$ & $41.72 \pm 2.71^{b}$ & $39.65 \pm 1.41^{\mathrm{b}}$ & $38.63 \pm 0.80^{b}$ \\
\hline
\end{tabular}

${ }^{5}$ Data are (expressed as) mean percentage \pm SE. Values in the same row that do not share the same superscript letter are significantly different according to analysis of variance and Duncan's post hoc procedures $(p<.05)$; nd not detected 
Table 3 SHR erythrocyte monounsaturated fatty acid composition (\%total fatty acids) following the consumption of diets with a 25:1 $\omega-6 / \omega-3$ FAR for 6 weeks ${ }^{\S}$

\begin{tabular}{|c|c|c|c|c|c|c|}
\hline \multirow[b]{2}{*}{ Fatty acid } & \multirow[b]{2}{*}{ Structure } & \multicolumn{5}{|c|}{ Dietary Group } \\
\hline & & AIN-76A & $C$ & CG & $\mathrm{PL}$ & SPG \\
\hline Undecenoic & C11:1 & nd & nd & nd & nd & nd \\
\hline Dodecenoic & C12:1 & nd & nd & nd & nd & nd \\
\hline Tridecanoic & C13:1 & nd & nd & nd & nd & nd \\
\hline Myristoleic & C14:1n5 & nd & nd & nd & nd & nd \\
\hline Pentadecenoic & C15:1n5 & $0.58 \pm 0.08^{a}$ & $0.04 \pm 0.00^{b}$ & $0.06 \pm 0.00^{b}$ & $0.06 \pm 0.01^{b}$ & $0.06 \pm 0.00^{b}$ \\
\hline Palmitoleic & C16:1n7 & $0.28 \pm 0.05^{\mathrm{a}}$ & $0.14 \pm 0.01^{\mathrm{b}}$ & $0.16 \pm 0.01^{b}$ & $0.15 \pm 0.02^{b}$ & $0.10 \pm 0.02^{b}$ \\
\hline Palmitelaidic & $\mathrm{C} 16: 1 \mathrm{n} 7 \mathrm{t}$ & $0.43 \pm 0.04^{a}$ & $0.41 \pm 0.05^{\mathrm{a}}$ & $0.35 \pm 0.05^{a}$ & $0.37 \pm 0.04^{a}$ & $0.56 \pm 0.03^{b}$ \\
\hline Heptadecenoic & C17:1n7 & nd & nd & nd & nd & nd \\
\hline Elaidic & C18:1n9t & nd & nd & nd & nd & nd \\
\hline Vaccenic & C18:1n11c & nd & nd & nd & nd & nd \\
\hline Trans-vaccenic & $\mathrm{C} 18: 1 \mathrm{n} 7 \mathrm{t}$ & nd & nd & nd & nd & nd \\
\hline Oleic & C18:1n9c & $5.60 \pm 0.61^{a}$ & $9.41 \pm 0.33^{c}$ & $8.56 \pm 0.35^{b c}$ & $8.55 \pm 0.25^{b c}$ & $7.76 \pm 0.23^{b}$ \\
\hline Cis-vaccenic & C18:1n7c & $1.30 \pm 0.17^{\mathrm{a}}$ & $1.88 \pm 0.08^{b}$ & $1.71 \pm 0.07^{b}$ & $1.78 \pm 0.06^{b}$ & $2.31 \pm 0.09^{c}$ \\
\hline cis-5 Eicosenoic & C20:1n15 & nd & $0.31 \pm 0.04$ & nd & nd & nd \\
\hline cis-8-Eicosenoic & C20:1n12 & nd & $0.26 \pm 0.03$ & nd & nd & nd \\
\hline Eicosenoic & C20:1n9 & $0.07 \pm 0.00^{a}$ & $0.26 \pm 0.03^{b}$ & $0.23 \pm 0.04^{b}$ & $0.19 \pm 0.03^{\mathrm{ab}}$ & $0.22 \pm 0.02^{b}$ \\
\hline Erucic & C22:1n9 & nd & nd & nd & nd & nd \\
\hline Nervonic & C24:1n9 & $0.90 \pm 0.20^{a}$ & $2.38 \pm 0.23^{b}$ & $2.03 \pm 0.19^{b}$ & $2.61 \pm 0.41^{b}$ & $4.08 \pm 0.40^{c}$ \\
\hline Total MUFAs & & $9.09 \pm 1.01^{\mathrm{a}}$ & $15.10 \pm 0.25^{\complement}$ & $13.11 \pm 0.35^{b}$ & $13.64 \pm 0.39^{b c}$ & $14.98 \pm 0.70$ \\
\hline
\end{tabular}

${ }^{\S}$ Data are (expressed as) mean percentage \pm SE. Values in the same row that do not share the same superscript letter are significantly different according to analysis of variance and Duncan's post hoc procedures $(p<.05)$; nd not detected

SHRs assigned to the control $(40.30 \pm 2.91), C G(45.50 \pm$ 2.95), PL (46.70 \pm 1.49$)$ and SPG $(46.51 \pm 1.04)$ diets versus the standardized control diet $(19.32 \pm 2.81)$ (Table 4$)$. In comparison to the control diet, slightly lower percentages of linoleic acid were present in the erythrocytes of SHRs consuming diets containing CG $(8.69 \pm 0.12)$ and PL (9.15 \pm 0.19$)$, while a significantly greater percentage of this fatty acid was present following the consumption of the diet containing SPG $(10.3 \pm 0.37)$. A greater percentage of $\alpha$-linolenic acid was found in the erythrocytes of SHRs consuming diets containing CG $(0.24 \pm 0.07)$, PL (0.48 \pm $0.22)$ and SPG $(0.31 \pm 0.02)$ in contrast to those consuming the standardized control and control diet.

\section{Discussion}

To evaluate the hypothesis that the addition of collard greens (CG), purslane (PL) or sweet potato greens (SPG) into diets with a $25: 1 \omega-6 / \omega-3$ FAR will favorably modify the erythrocyte fatty acid profile, the present research was undertaken to determine the effects of the consumption of these GLVs on erythrocyte fatty acid profiles of spontaneously hypertensive rats (SHRs). Remarkably, diets supplemented with these GLVs mediated an increase in both erythrocyte mono- and polyunsaturated fatty acids, which may be beneficial in reducing the risk associated with chronic disease.

Previous research has demonstrated the ability of the $\omega-6 / \omega-3$ FAR (i.e. linoleic acid: $\alpha$-linolenic acid) to influence plasma docosahexaenoic acid (DHA) concentrations [27]. In a study by Ponder et al., erythrocyte DHA concentration increased by $20 \%$ when the linoleic: alpha linolenic acid (LA:ALA) ratio was decreased [28]. In addition to the $\omega-6 / \omega-3$ FAR, dietary fatty acids are able to influence the erythrocyte fatty acid composition [29], which in turn is believed to be a customary indicator of long-term fatty acid intake [30]. Earlier studies found the induction of marginal changes in erythrocyte fatty acid composition by dietary fat [31]. This relationship becomes even more pronounced as the erythrocyte fatty acid composition may be an indicator of disease risk, with the PUFA content of erythrocytes being inversely associated with metabolic syndrome [32]. Reductions in erythrocyte omega-3 fatty acids have been associated with depression [33], attention deficit disorder [34] and other common mood disorders $[35,36]$. Further, it has been suggested that omega-3 fatty acid deficiency may serve as a critical element in understanding the relationship between depression and cardiovascular diseases [37, 38]. Epidemiological evidence 
Table 4 SHR erythrocyte polyunsaturated fatty acid composition (\%total fatty acids) following the consumption of diets with a 25:1 $\omega-6 / \omega-3$ FAR for 6 weeks ${ }^{5}$

\begin{tabular}{|c|c|c|c|c|c|c|}
\hline \multirow[b]{2}{*}{ Fatty acid } & \multirow[b]{2}{*}{ Structure } & \multicolumn{5}{|l|}{ Dietary Group } \\
\hline & & AIN-76A & C & CG & $\mathrm{PL}$ & SPG \\
\hline Linoelaidic & $C 18: 2 n 6 t$ & nd & nd & nd & nd & nd \\
\hline Linoleic & $\mathrm{C} 18: 2 \mathrm{n} 6 \mathrm{c}$ & $3.68 \pm 0.31^{a}$ & $9.26 \pm 0.25^{b}$ & $8.69 \pm 0.12^{b}$ & $9.15 \pm 0.19^{b}$ & $10.31 \pm 0.37^{c}$ \\
\hline Y-Linolenic & C18:3n6 & $0.23 \pm 0.02^{\mathrm{a}}$ & $0.63 \pm 0.31^{\mathrm{a}}$ & $8.48 \pm 1.29^{b}$ & $6.43 \pm 2.09^{b}$ & $5.07 \pm 1.55^{\mathrm{b}}$ \\
\hline a-Linolenic & C18:3n3 & $0.10 \pm 0.04^{a}$ & $0.09 \pm 0.02^{\mathrm{a}}$ & $0.24 \pm 0.07^{\mathrm{a}}$ & $0.48 \pm 0.22^{\mathrm{a}}$ & $0.31 \pm 0.02^{\mathrm{a}}$ \\
\hline Eicosadienoic & $C 20: 2 n 6$ & $0.20 \pm 0.03^{\mathrm{a}}$ & nd & $0.51 \pm 0.02^{b c}$ & $0.56 \pm 0.03^{c}$ & $0.44 \pm 0.03^{b}$ \\
\hline Eicosatrienoic & $C 20: 3 n 6$ & $0.19 \pm 0.05^{\mathrm{a}}$ & $0.43 \pm 0.01^{b}$ & $0.40 \pm 0.03^{b}$ & $0.40 \pm 0.02^{b}$ & $0.57 \pm 0.03^{c}$ \\
\hline Arachidonic & $C 20: 4 n 6$ & $12.25 \pm 2.11^{\mathrm{a}}$ & $22.65 \pm 2.37^{b}$ & $22.41 \pm 1.69^{b}$ & $22.09 \pm 1.76^{b}$ & $21.67 \pm 0.87^{b}$ \\
\hline Eicosatrienoic & $C 20: 3 n 3$ & nd & $0.16 \pm 0.03^{\mathrm{a}}$ & $0.17 \pm 0.01^{\mathrm{a}}$ & nd & nd \\
\hline Eicosapentaenoic & C20:5n3 & nd & $0.29 \pm 0.07^{\mathrm{a}}$ & nd & nd & $1.41 \pm 0.23^{b}$ \\
\hline Docosadienoic & $C 22: 2 n 6$ & nd & nd & nd & nd & nd \\
\hline Docosatetraenoic & $\mathrm{C} 22: 4 \mathrm{n} 6$ & $1.30 \pm 0.24^{a}$ & $2.26 \pm 0.60^{b}$ & $2.02 \pm 0.17^{a b}$ & $2.79 \pm 0.34^{b}$ & $1.67 \pm 0.33^{\mathrm{ab}}$ \\
\hline Docosatrienoic & $C 22: 3 n 3$ & $0.78 \pm 0.23^{\mathrm{a}}$ & $1.12 \pm 0.12^{\mathrm{a}}$ & $0.84 \pm 0.08^{\mathrm{a}}$ & $1.07 \pm 0.18^{\mathrm{a}}$ & $0.71 \pm 0.12^{\mathrm{a}}$ \\
\hline Docosapentaenoic & $C 22: 5 n 3$ & nd & nd & nd & nd & nd \\
\hline Docosahexaenoic & C22:6n3 & $0.68 \pm 0.08^{\mathrm{a}}$ & $3.19 \pm 0.52^{\mathrm{bc}}$ & $1.78 \pm 0.15^{\mathrm{ab}}$ & $3.86 \pm 1.61^{c}$ & $4.48 \pm 0.67^{c}$ \\
\hline Total PUFAs & & $19.32 \pm 2.81^{a}$ & $40.30 \pm 2.91^{b}$ & $45.50 \pm 2.95^{b}$ & $46.70 \pm 1.49^{\mathrm{b}}$ & $46.51 \pm 1.04^{b}$ \\
\hline
\end{tabular}

${ }^{5}$ Data are (expressed as) mean percentage \pm SE. Values in the same row that do not share the same superscript letter are significantly different according to analysis of variance and Duncan's post hoc procedures $(p<.05)$; nd not detected

has affirmed that there exists an inverse relationship between omega-3 polyunsaturated fatty acid levels and cardiovascular disease [39-42]. However, others found omega-3 polyunsaturated fatty acid supplementation to not be associated with reductions in cardiovascular disease risk, morbidities and mortalities [43]. Further, inflammation and autoimmune diseases are believed to be exacerbated when there is insufficient omega-3 polyunsaturated fatty acids to combat the deleterious effects of pro-inflammatory cytokines and agents $[44,45]$.

Correcting the dietary deficiency of omega-3 fatty acids was found to favorably influence the fatty acid composition of erythrocytes in monkeys by increasing DHA content [46]. Supplementing omega-3 polyunsaturated fatty acids into the diets of pregnant women, resulted in increases in both maternal and neonatal erythrocyte concentrations of eicosapentaenoic acid (EPA) and DHA [47]. Lower levels of erythrocyte omega-3 fatty acids coupled with subsequent higher $\omega-6 / \omega-3$ FARs significantly increased the risk for preeclampsia among pregnant women [48]. In addition, the source of omega- 3 fatty acids was found to alter erythrocyte omega-3 fatty acid composition, with fish oil yielding a more pronounced increase in erythrocyte DHA and total omega-3 fatty acids than flaxseed oil [32].

In addition to a reduction in the $\omega-6 / \omega-3$ FAR, the egg yolk omega-3 fatty acid content was increased among chickens fed diets supplemented with purslane for 84 days [49]. In another study, the inclusion of purslane and/or flaxseed oil into the diets of laying hens yielded similar results, with the purslane resulting in increased egg yolk omega-3 fatty acids [50]. Modifying the $\omega-6 / \omega-3$ FAR has also been demonstrated to improve egg quality characteristics (e.g. egg weight, yolk weight, shell weight) in hens, as well as facilitating the production of eggs with higher omega- 3 and other polyunsaturated fatty acid contents [51]. In this same study, greater dietary $\omega-6 / \omega-3$ FARs yielded unfavorable egg characteristics that may have an adverse impact on consumer health. Increased percentages of these fatty acids may act as cellular antioxidants thwarting oxidative and inflammatory pathways implicated in disease pathogenesis [52, 53].

Lower $\omega-6 / \omega-3$ FARs are desirable in reducing the risks associated with cardiovascular and other diseases [54, 55]; it has been suggested that increasing the dietary intake of omega-3 fatty acids is a viable option for optimizing tissue $\omega-6 / \omega-3$ FARs $[2,56]$. In the current research study a $25: 1$ $\omega-6 / \omega-3$ FAR was examined, as this is the ratio found in the typical Western diet (i.e. American). Collard greens, purslane and sweet potato greens, incorporated into the experimental diets of the current study, have demonstrated beneficial cardioprotective, chemopreventive and anti-inflammatory effects in previous studies [57-63]. The inclusion of these GLVs resulted in increased mono- and polyunsaturated fatty acid percentages within the SHR erythrocyte, which may in turn decrease the risks associated with disease pathogenesis in an animal model predisposed to developing hypertension and other associated comorbidities. 


\section{Conclusions}

The findings of this research study provide evidence of the ability of collard greens, purslane and sweet potato greens to modify the erythrocyte fatty acid profile, even in the presence of diets with an elevated omega-6/omega-3 fatty acid ratio. The inclusion of GLVs into diets with greater than recommended omega-6/omega-3 fatty acid ratios may be useful in amending tissue and cellular fatty acid profiles in ways that may be useful in mitigating disease risk. Further, the increased PUFA and omega-3 fatty acid content of SHR erythrocytes consuming diets containing these green leafy vegetables suggest the antioxidant and erythroprotective nature of these vegetables and their potential use as a functional food with therapeutic consequences.

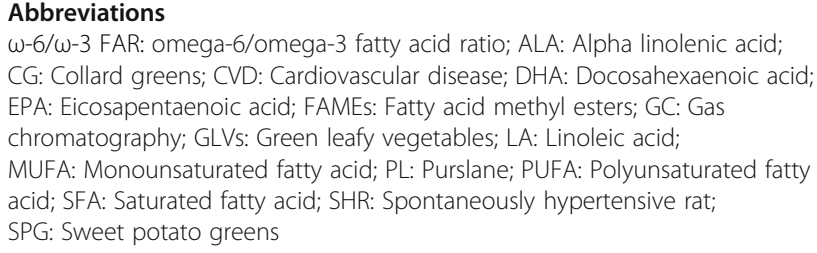

\section{Acknowledgements}

Dr. Daniel Abugri provided invaluable consultation and technical services during the research study.

\section{Funding}

This research was supported by the Tuskegee University College of Agriculture, Environment and Nutrition Sciences and The Alabama Collaboration for Cardiovascular Equality (ACCE).

\section{Availability of data and materials}

All data generated or analyzed during this study are included in this published article.

\section{Authors' contributions}

MJ contributed to the conception and design of the study, performed the animal study, erythrocyte fatty acid profile analysis, analyzed data, drafted and edited the manuscript. RDP contributed to the design of the study, supervised the project and edited the manuscript. WHM contributed to the design of the study, assisted in the statistical analysis of the data and edited the manuscript. All authors read and approved the final manuscript.

\section{Ethics approval}

The procedures involved in the care and use of the animals were approved by the Tuskegee University Animal Care and Use Committee (Tuskegee, AL, USA).

\section{Consent for publication}

Not applicable.

\section{Competing interests}

The authors declare that they have no competing interests.

\section{Publisher's Note}

Springer Nature remains neutral with regard to jurisdictional claims in published maps and institutional affiliations.

\section{Author details}

${ }^{1}$ Department of Food and Nutritional Sciences, Tuskegee University, Tuskegee, AL 36088, USA. ²Department of Agricultural and Environmental Sciences, Tuskegee University, Tuskegee, AL 36088, USA.
Received: 12 July 2017 Accepted: 25 March 2018

Published online: 15 June 2018

\section{References}

1. Simopoulos AP. The omega-6/omega-3 fatty acid ratio, genetic variation, and cardiovascular disease. Asia Pac J Clin Nutr. 2008;17(Suppl 1):131-4.

2. Harris WS, Assaad B, Poston WC. Tissue omega-6/omega-3 fatty acid ratio and risk for coronary artery disease. Am J Cardiol. 2006;98:19-26.

3. Simopoulos AP. Omega-6/Omega-3 essential fatty acid ratio and chronic diseases. Food Rev Intl. 2004;20:77-90.

4. Riediger ND, Othman R, Fitz E, Pierce GN, Suh M, Moghadasian MH. Low n6: $n-3$ fatty acid ratio, with fish-or flaxseed oil, in a high fat diet improves plasma lipids and beneficially alters tissue fatty acid composition in mice. Eur J Nutr. 2008;47:153-60.

5. Kearns RJ, Hayek MG, Turek JJ, Meydani M, Burr JR, Greene RJ, Marshall CA, Adams SM, Borgert RC, Reinhart GA. Effect of age, breed and dietary omega-6 (n-6): omega-3 (n-3) fatty acid ratio on immune function, eicosanoid production, and lipid peroxidation in young and aged dogs. Vet Immunol Immunopathol. 1999;69:165-83.

6. Simopoulos AP. Evolutionary aspects of omega-3 fatty acids in the food supply. Prostaglandins Leukot Essent Fatty Acids. 1999;60:421-9.

7. Simopoulos AP, Leaf A, Salem N Jr. Essentiality of and recommended dietary intakes for omega-6 and omega-3 fatty acids. Ann Nutr Metab. 1999; 43:127-30.

8. Kris-Etherton PM, Taylor DS, Yu-Poth S, Huth P, Moriarty K, Fishell V, Hargrove RL, Zhao G, Etherton TD. Polyunsaturated fatty acids in the food chain in the United States. Am J Clin Nutr. 2000;71:179S-88S.

9. Simopoulos AP. Evolutionary aspects of diet, the omega-6/omega-3 ratio and genetic variation: nutritional implications for chronic diseases. Biomed Pharmacother. 2006;60:502-7.

10. Russo GL. Dietary $n-6$ and $n-3$ polyunsaturated fatty acids: from biochemistry to clinical implications in cardiovascular prevention. Biochem Pharmacol. 2009;77:937-46.

11. Hu FB. Plant-based foods and prevention of cardiovascular disease: an overview. Am J Clin Nutr. 2003:78:544S-51S

12. Coulston AM. The role of dietary fats in plant-based diets. Am J Clin Nutr. 1999;70:512s-5s.

13. Kris-Etherton PM, Hecker KD, Bonanome A, Coval SM, Binkoski AE, Hilpert KF Griel $A E$, Etherton TD. Bioactive compounds in foods: their role in the prevention of cardiovascular disease and cancer. Am J Med. 2002;113:71-88.

14. Lundberg JO, Feelisch M, Bjorne $\mathrm{H}$, Jansson EA, Weitzberg E. Cardioprotective effects of vegetables: is nitrate the answer? Nitric Oxide. 2006:15:359-62.

15. de Lorgeril M, Salen P. The Mediterranean-style diet for the prevention of cardiovascular diseases. Public Health Nutr. 2006:9:118-23.

16. de Lorgeril M, Salen P. Modified Cretan Mediterranean diet in the prevention of coronary heart disease and cancer. World Rev Nutr Diet. 2000;87:1-23.

17. Huang Z, Wang B, Eaves DH, Shikany JM, Pace RD. Total phenolics and antioxidant capacity of indigenous vegetables in the Southeast United States: Alabama collaboration for cardiovascular equality project. Int J Food Sci Nutr. 2009;60:100-8

18. Huang Z, Wang B, Eaves DH, Shikany JM, Pace RD. Phenolic compound profile of selected vegetables frequently consumed by African Americans in the Southeast United States. Food Chem. 2007;103:1395-402.

19. Hu FB. Dietary pattern analysis: a new direction in nutritional epidemiology. Curr Opin Lipidol. 2002:13:3-9.

20. Fung TT, Chiuve SE, McCullough ML, Rexrode KM, Logroscino G, Hu FB. Adherence to a DASH-style diet and risk of coronary heart disease and stroke in women. Arch Intern Med. 2008;168:713-20.

21. Most MM. Estimated phytochemical content of the dietary approaches to stop hypertension (DASH) diet is higher than in the control study diet. J Am Diet Assoc. 2004;104:1725-7

22. Sacks FM, Moore TJ, Appel LJ, Obarzanek E, Cutler JA, Vollmer WM, Vogt TM Karanja N, Svetkey LP, Lin PH. A dietary approach to prevent hypertension: a review of the dietary approaches to stop hypertension (DASH) study. Clin Cardiol. 1999;22:6-10.

23. Oduro I, Ellis W, Owusu D. Nutritional potential of two leafy vegetables: Moringa oleifera and Ipomoea batatas leaves. Sci Res Essays. 2008;3:57-60.

24. Johnson M, Pace RD. Sweet potato leaves: properties and synergistic interactions that promote health and prevent disease. Nutr Rev. 2010;68:604-15. 
25. Johnson M, Pace RD, Dawkins NL, Willian KR. Diets containing traditional and novel green leafy vegetables improve liver fatty acid profiles of spontaneously hypertensive rats. Lipids Health Dis. 2013;12:168.

26. Masood A, Stark KD, Salem N Jr. A simplified and efficient method for the analysis of fatty acid methyl esters suitable for large clinical studies. J Lipid Res. 2005:46:2299-305.

27. Makrides M, Neumann MA, Jeffrey B, Lien EL, Gibson RA. A randomized trial of different ratios of linoleic to a-linolenic acid in the diet of term infants: effects on visual function and growth. Am J Clin Nutr. 2000;71:120-9.

28. Ponder DL, Innis SM, Benson JD, Siegman JS. Docosahexaenoic acid status of term infants fed breast milk or infant formula containing soy oil or corn oil. Pediatr Res. 1992;32:683-8.

29. Putnam JC, Carlson SE, DeVoe PW, Barness LA. The effect of variations in dietary fatty acids on the fatty acid composition of erythrocyte phosphatidylcholine and phosphatidylethanolamine in human infants. Am J Clin Nutr. 1982;36:106-14.

30. Sun Q, Ma J, Campos H, Hankinson SE, Hu FB. Comparison between plasma and erythrocyte fatty acid content as biomarkers of fatty acid intake in US women. Am J Clin Nutr. 2007:86:74-81.

31. Farquhar JW, Ahrens EH Jr. Effects of dietary fats on human erythrocyte fatty acid patterns. J Clin Inves. 1963;42:675-85.

32. Barceló-Coblijn G, Murphy EJ, Othman R, Moghadasian MH, Kashour T, Frie JK. Flaxseed oil and fish-oil capsule consumption alters human red blood cell $n-3$ fatty acid composition: a multiple-dosing trial comparing 2 sources of $n-3$ fatty acid. Am J Clin Nutr. 2008;88:801-9.

33. Peet M, Murphy B, Shay J, Horrobin D. Depletion of omega-3 fatty acid levels in red blood cell membranes of depressive patients. Biol Psychiatry. 1998:43:315-9.

34. Stevens L, Zentall SS, Deck JL, Abate ML, Watkins BA, Lipp SR, Burgess JR. Essential fatty acid metabolism in boys with attention-deficit hyperactivity disorder. Am J Clin Nutr. 1995;62:761-8.

35. Parker G, Gibson NA, Brotchie H, Heruc G, Rees AM, Hadzi-Pavlovic D. Omega-3 fatty acids and mood disorders. Am J Psychiatry. 2006;163:969-78.

36. Osher Y, Belmaker R. Omega-3 fatty acids in depression: a review of three studies. CNS Neurosci Ther. 2009:15:128-33.

37. Severus WE, Littman AB, Stoll AL. Omega-3 fatty acids, homocysteine, and the increased risk of cardiovascular mortality in major depressive disorder. Harv Rev Psychiatry. 2001;9:280-93.

38. Joynt KE, Whellan DJ, O'Connor CM. Depression and cardiovascular disease: mechanisms of interaction. Biol Psychiatry. 2003;54:248-61.

39. Dolecek TA. Epidemiological evidence of relationships between dietary polyunsaturated fatty acids and mortality in the multiple risk factor intervention trial. Exp Biol Med. 1992;200:177-82.

40. Lavie CJ, Milani RV, Mehra MR, Ventura HO. Omega-3 polyunsaturated fatty acids and cardiovascular diseases. J Am Coll Cardiol. 2009;54:585-94.

41. von Schacky C. Omega-3 fatty acids and cardiovascular disease. Curr Opin Clin Nutr Metab Care. 2007;10:129-35.

42. Kris-Etherton PM, Harris WS, Appel LJ. Fish consumption, fish oil, omega-3 fatty acids, and cardiovascular disease. Circulation. 2002;106:2747-57.

43. Rizos EC, Ntzani EE, Bika E, Kostapanos MS, Elisaf MS. Association between omega-3 fatty acid supplementation and risk of major cardiovascular disease events: a systematic review and meta-analysis. JAMA. 2012;308:1024-33.

44. Simopoulos AP. Omega-3 fatty acids in inflammation and autoimmune diseases. J Am Coll Nutr. 2002:21:495-505.

45. Johnson M, Bradford C. Omega-3, omega-6 and omega-9 fatty acids: implications for cardiovascular and other diseases. J Glycomics Lipidomics. 2014:4:2153-0637.1000123.

46. Connor WE, Neuringer M, Lin DS. Dietary effects on brain fatty acid composition: the reversibility of $n-3$ fatty acid deficiency and turnover of docosahexaenoic acid in the brain, erythrocytes, and plasma of rhesus monkeys. J Lipid Res. 1990;31:237-47.

47. Dunstan JA, Mori TA, Barden A, Beilin L, Holt P, Calder P, Taylor A, Prescott S. Effects of $n-3$ polyunsaturated fatty acid supplementation in pregnancy on maternal and fetal erythrocyte fatty acid composition. Eur J Clin Nutr. 2004:58:429-37.

48. Williams MA, Zingheim RW, King IB, Zebelman AM. Omega-3 fatty acids in maternal erythrocytes and risk of preeclampsia. Epidemiology. 1995:6(3):232-7.

49. Aydin R, Dogan I. Fatty acid profile and cholesterol content of egg yolk from chickens fed diets supplemented with purslane (Portulaca oleracea L.). J Sci Food Agric. 2010;90:1759-63.

50. Evaris E, Sarmiento-Franco LA, Segura-Correa J, Capetillo-Leal C. Effect of dietary inclusion of purslane (Portulaca oleraca L.) on yolk omega-3 fatty acids content. Egg quality and productive performance of Rhode Island red hens. Trop Subtrop Agroecosyst. 2015;18:33-8.

51. Hamady G. Effects of different ratios of dietary omega- 6 to omega-3 fatty acids on laying performance and egg quality of Lohmann Brown hens. Egypt Poult Sci J. 2013;33:957-69.

52. Richard D, Kefi K, Barbe U, Bausero P, Visioli F. Polyunsaturated fatty acids as antioxidants. Pharmacol Res. 2008;57:451-5.

53. Calder PC. N- 3 polyunsaturated fatty acids and inflammation: from molecular biology to the clinic. Lipids. 2003;38:343-52.

54. Simopoulos AP. The importance of the Omega-6/Omega-3 fatty acid ratio in cardiovascular disease and other chronic diseases. Exp Biol Med. 2008; 233:674-88

55. Chajes V, Bougnoux P. Omega-6/omega-3 polyunsaturated fatty acid ratio and cancer. World Rev Nutr Diet. 2003;92:133-51.

56. Harris WS. The omega-6/omega-3 ratio and cardiovascular disease risk: uses and abuses. Curr Atheroscler Rep. 2006;8:453-9.

57. Kurata R, Kobayashi T, Ishii T, Niimi H, Niisaka S, Kubo M, Kishimoto M. Influence of sweet potato (Ipomoea batatas L.) leaf consumption on rat lipid metabolism. Food Sci Technol Res. 2017;23:57-62.

58. Nagai M, Tani M, Kishimoto Y, lizuka M, Saita E, Toyozaki M, Kamiya T, Ikeguchi M, Kondo K. Sweet potato (Ipomoea batatas L.) leaves suppressed oxidation of low density lipoprotein (LDL) in vitro and in human subjects. J Clin Biochem Nutr. 2011;48:203-8.

59. Ayeleso TB, Ramachela K, Mukwevho E. A review of therapeutic potentials of sweet potato: pharmacological activities and influence of the cultivar. Trop J Pharm Res. 2016:15:2751-61.

60. Noorbakhshnia M, Karimi-Zandi L. Portulaca oleracea L. prevents lipopolysaccharide-induced passive avoidance learning and memory and TNF-a impairments in hippocampus of rat. Physiol Behav. 2017;169:69-73.

61. Ramadan BK, Schaalan MF, Tolba AM. Hypoglycemic and pancreatic protective effects of Portulaca oleracea extract in alloxan induced diabetic rats. BMC Complement Altern Med. 2017;17:37.

62. Miller-Cebert RL, Boateng J, Cebert E, Shackelford L, Verghese M. Chemopreventive potential of canola leafy greens and other cruciferous vegetables on Azoxymethane (AOM)-induced Colon Cancer in Fisher-344 male rats. Food Nutr Sci. 2016;7:964

63. Pollock RL. The effect of green leafy and cruciferous vegetable intake on the incidence of cardiovascular disease: a meta-analysis. JRSM Cardiovasc Dis. 2016:5:2048004016661435.

\section{Submit your next manuscript to BioMed Central and we will help you at every step:}

- We accept pre-submission inquiries

- Our selector tool helps you to find the most relevant journal

- We provide round the clock customer support

- Convenient online submission

- Thorough peer review

- Inclusion in PubMed and all major indexing services

- Maximum visibility for your research

Submit your manuscript at www.biomedcentral.com/submit 